\title{
IMPROVING STUDENTS' MOTORIC SKILLS THROUGH DEMONSTRATION METHOD IN RECYCLING PLASTIC WASTE
}

\author{
Ilmi Zajuli Ichsan ${ }^{1 *}$ and Surandini Wahyu Widi Mulyani ${ }^{2}$ \\ ${ }^{1}$ Biology Education, Faculty of Mathematics and Natural Science, \\ State University of Jakarta, Indonesia \\ ${ }^{2}$ State Junior High School (SMPN) 1 of South Tambun, Bekasi, West Java, Indonesia \\ *Corresponding e-mail: ilmizajuli95@gmail.com
}

\begin{abstract}
One of the obstacles faced in school is the low motoric skills of students in recycling waste meanwhile the motoric skills are one of the learning outcomes that must be developed. The purpose of this research was to improve students' motoric skills in recycling plastic waste. This Classroom Action Research was conducted in three cycles. The subjects in this research were 34 students in the $7^{\text {th }}$ grade. The data was collected using an observation method in which the skill indicators instrument utilized was adopted from Arikunto. The research was conducted in March 2018. The results showed that there was an increasing trend of students' motoric skills in each cycle. On the other words, the demonstration method can improve students' motoric skills in recycling plastic waste.
\end{abstract}

Keywords: Demonstration, motoric skills, plastic waste, recycling

(C) 2018 Department of Biology Education, FTTE, University of Muhammadiyah Malang, Indonesia

\section{INTRODUCTION}

Technology developments in $21^{\text {st }}$-century require students to have the ability to cope with the challenges of their lives, including good motoric skills. Student motoric skills are part of the learning outcomes that must be measured and observed from the learning process (Derri \& Pachta, 2007; Loprinzi, Davis, \& Fu, 2015; Teodora Mihaela \& Laurentiu-Gabriel, 2014). Motoric skills are the result of a relatively permanent change in the ability to perform a skill as a result of training or experience. The existence of motoric skills to optimize the ability to perform skills at the level of success, precision, and to reduce the energy consumption required for performance. The practice of certain motoric skills that will constantly produce a good performance in individual life (Cantell, Crawford, \& (Tish) Doyle-Baker, 2008; Isbell \& Isbell, 2007; Ziegler \& Stoeger, 2010).

Motoric skills are intertwined with cognitive abilities. In physical learning, the student needs cognitive concepts when learning the body move while performing motoric skills (Derri \& Pachta, 2007; Donnelly, Mueller, Gallahue, \& Gallahue, 2017; Piek, Dawson, Smith, \&
Gasson, 2008). The success of the learning process in improving student skills is an important aspect to ensure students' learning skills in a real-life context (Amin, 2010; Gay, Mills, \& Airasian, 2012; Lederman, Lederman, \& Antink, 2013).

However, the implementation in schools is not always in line with the ideal conditions that have been established. Based on observations at State Junior High School (SJHS) 1 of South Tambun-Bekasi at the West Java, the students' motoric skills are still low. The teacher's assessment only focuses on the aspects of cognitive learning outcomes so that aspects of the assessment of students' motor skills are not done properly. Loprinzi, Cardinal, Loprinzi, and Lee (2012) state that the lack of motoric skills of students in the classroom needs to increase with the utilization of environmental around the students

The learning process undertaken so far has not been developed in contextual learning so that students also have a low sensitivity to problems that arise in their environment, such as environmental hygiene. In fact, the school is a fairly as high producer of plastic waste. This is derived from the consumption of processed food ingredients in schools that are mostly 
packed using products made from plastic. It causes a lot of plastic waste found in schools. Teachers can take advantage of the problems that exist in the student environment to build motoric skills (Isbell \& Isbell, 2007; Loprinzi et al., 2012; Teodora Mihaela \& LaurentiuGabriel, 2014). The student can learn how to solve the problem by recycling the waste into recyclable products that have economic value (Hama \& Hilal, 2017; Surono \& Ismanto, 2016).

Thus, students' motoric skills can be improved by using learning strategies to make the plastic waste problem as a learning resource in the learning process. Plastic waste problem is one kind of environmental issue that gives students contextual learning experience. It is important to build sensitivity and to train their skills in solving problems around them (Bidokht \& Assareh, 2011; Prajina, 2014; Teodora Mihaela \& Laurentiu-Gabriel, 2014). The statement is in line with Chuvgunova and Kostromina (2016); Andini, Susanto, and Hobri (2017); Adhitama, Kusnadi, and Supriatno (2014) which states that the learning process is a strategic way to improve students' motoric skills.

The most appropriate method to train and improve students' skills are through demonstration method (Doussoulin \& Rehbein, 2011; McCullagh \& Little, 1990; Teodora Mihaela \& Laurentiu-Gabriel, 2014; Vrbik \& Vrbik, 2017). This method is a popular way used in the learning process that aims to improve students' motoric skill. In addition, this method also has a positive impact in increasing cooperation among students and student understanding (Basheer, Hugerat, Kortam, \& Hofstein, 2017; Noah Ekeyi, 2013; Polizzotto \& Tamari, 2015; Ramsey, Walczyk, Deese, \& Eddy, 2000; Ranya, Jamhari, \& Rede, 2013). Demonstration method is usually combined with other methods such as questioning and answering as well as discussions method. It aims to make students more active and make learning better.

Regarding that situation, it becomes very important to conduct studies related to the improvement of students' motoric skills through the utilization of environmental problems, such as plastic waste, in schools into various recycled products. Observation and assessment of students' skills include all learning activities from the process of making the product to the presentation of the final product.

\section{METHOD}

This Classroom Action Research (CAR) study was conducted at SJHS 1 of South Tambun, Bekasi Regency at the West Java in March 2018. The subject of this study were 34 students in $7^{\text {th }}$ grade. This research consists of 3 cycles. The first cycle used conventional methods, while other cycles are treated with demonstration method.

The skills assessment instrument used consist of 12 statement items with a score scale of 1-5 in each item. This instrument was adopted from Arikunto (2012) as in Table 1. The data were collected by observation and analyzed by seeing the gain score of each cycle. The gain scores are obtained by the Formula 1, expressed by Fauziyah \& Jailani (2014).

$$
\text { Gain }=\frac{\text { Average score cycle } 2-\text { Average score cycle } 1}{100-\text { Average score cycle } 1}
$$

Table 1. Indicators of skills instrument

\begin{tabular}{llc}
\hline \multicolumn{1}{c}{ Aspect } & \multicolumn{1}{c}{ Indicators } & Item \\
\hline $\begin{array}{l}\text { Muscular/ } \\
\text { Motoric Skill }\end{array}$ & $\begin{array}{l}\text { Display the work in front } \\
\text { of a classmate } \\
\text { Shows the process of } \\
\text { work to the teacher }\end{array}$ & 1,2 \\
& $\begin{array}{l}\text { Form a work with raw } \\
\text { materials that have been } \\
\text { prepared }\end{array}$ & 5,6 \\
$\begin{array}{l}\text { Manipulation of } \\
\text { materials or } \\
\text { object }\end{array}$ & $\begin{array}{l}\text { Prepare the composition } \\
\text { of the material properly } \\
\text { and neatly }\end{array}$ & 7,8 \\
& $\begin{array}{l}\text { Blending various } \\
\text { colors/shades for the work } \\
\text { looks beautiful }\end{array}$ & 9,10 \\
$\begin{array}{l}\text { Neuromuscular various tools well and } \\
\text { Coordination }\end{array}$ & 11, \\
& \multicolumn{1}{c}{12} \\
\hline
\end{tabular}

The results are interpreted using scores according to the criteria expressed by Puspitorini, Prodjosantoso, Subali, and Jumadi (2014) as presented in Table 2.

Table 2. Gain score criteria

\begin{tabular}{cc}
\hline Gain Score & Criteria \\
\hline $\mathrm{g} \geq 0,7$ & High \\
$0,7>\mathrm{g} \geq 0,3$ & Middle \\
$\mathrm{g}<0,3$ & Low \\
\hline
\end{tabular}

\section{RESULT AND DISCUSSION}

The students' skills assessment are obtained through observation at each cycle. The score of students' skills are calculated based on the grade average in each cycle. The students' skill score on Cycle 1 is 64, whereas in Cycle 2 and 
Cycle 3 are 91.1 and 94.3 respectively. The average of students' skills score is presented in Table 3 .

Table 3. The average score of students' skills

\begin{tabular}{cc}
\hline Step & Average score \\
\hline Cycle 1 & 64.0 \\
Cycle 2 & 91.1 \\
Cycle 3 & 94.3 \\
\hline
\end{tabular}

The result of the average score is then calculated by the gain formula to obtain 3 types of gain score. This score is calculated to see the magnitude of the increase in each cycle. The result of gain score can be seen in Table 4 .

Table 4. Result interpretation gain score each cycle

\begin{tabular}{ccc}
\hline Step & Gain score & Criteria \\
\hline Cycle 1 - Cycle 2 & 0.7 & High \\
Cycle 2 - Cycle 3 & 0.3 & Medium \\
Cycle 1 - Cycle 3 & 0.8 & High \\
\hline
\end{tabular}

The results obtained are categorized high on Cycle 1 through Cycle 2 and Cycle 1 through Cycle 3, while the results of Cycle 2 to cycle 3 are medium. These results indicate that there is an increase in students' skills at the time after being given treatment in the form of demonstration method. In the Cycle 1, planning phases until reflection are passed without treatment. In this phase, the teacher would like to see the student's ability on the initial condition. In contrast to Cycle 2, during the planning phase, the teacher create a plan to make students more active. The plan is implemented in the action phase. In this phase, the teacher gives a demonstration to the students in front of the class. Then the students' skills are measured in the observation phase. In the reflection phase, teachers and students alike do it.

The implementation of Cycle 3 is based on the results of previous cycle reflection. The students are given instructions during demonstrations and done in groups. This turned out to have a good impact. Demonstration method are useful methods to clarify instructions to students.

Actually, demonstration method is not a new method, but many teachers have not applied it to ease the learning process in the classroom. Other research results also show that demonstration method make learning better than lecture methods (Bulut, 2012; McCullagh \& Little, 1990; Noah Ekeyi, 2013; Polizzotto \&
Tamari, 2015; Ramsey et al., 2000; Umar, Bala, \& Ladu, 2016). Teachers can provide clearer direction when a demonstration method is used and the students also be easier to grasp the intentions conveyed by the teacher. The explanation of the making of flowers from the waste is more easily understood when a demonstration method is used. Students will find it easier to understand, and the teacher does not waste too much energy explaining the same thing over and over again (Polizzotto \& Tamari, 2015; Ramsey et al., 2000).

Demonstration method can use learning media such as animation video. Animation video is interesting for students (Islam, Ahmed, Islam, \& Shamsuddin, 2014; Pruneski \& Donovan, 2007; Vrbik \& Vrbik, 2017) and can run with many hardware like projector and laptop (Yusuf, Amin, \& Nugrahaningsih, 2017). This demonstration method can also be replaced with online-based media so that lteachers may not need to come to class to explain. This has a positive impact that is more efficient but has a negative impact as well. The negative impact is that demonstration methods require direct clarification, for which teachers should be present in the classroom to clarify directly to students if students find difficulty (Nordin \& Alias, 2013).

Through demonstration method proven there is an improvement of students' skill score. This can be evidenced by high and medium gain scores. A high score shows a high skill score increase. At Cycle 2 compared to Cycle 1, the gain score is categorized high. This high category is due to students getting clear orders that make group collaboration more organized. According to Derri and Pachta (2007) and also Navarro-Pablo and Gallardo-Saborido (2015), group learning makes good learning outcomes in terms of cognitive, affective, and psychomotor.

Demonstration method can also be added by using audiovisual media. Media such as videos, movies, or songs can be used to add attraction while using demonstration method. Media can be used to improve learning outcomes is through online applications (Anjarwati, Winarno, \& Churiyah, 2016; Uzun, 2012; Walker, 2003). In addition, students will be enthusiastic and more active when given a video tutorial or it could be a short film (Ichsan, Rusdi, \& Sartono, 2017; Pruneski \& Donovan, 2007; Soika, Reiska, \& Mikser, 2010). 
Books can actually be used as companion media in the demonstration method, but there are some aspects that must be considered in delivering the material. In fact, student package books is sometimes incomplete explaining all the material (Nugroho, Vlorensius, Rasidah H., \& Anisa, 2017). In principle, all learning resource used should be able to make students actively.

Active learning will support the achievement of learning outcomes optimally, because students will understand the concept of learning correctly (Sesen \& Tarhan, 2010; Uzun, 2012). Students who understand the concept of learning correctly will certainly increase the learning outcomes both in terms of cognitive and psychomotor. In addition to learning media and demonstration methods that enhance motoric skill. Apparently, environmental problems become one of the interesting aspects of learning. Based on the results of the study it was found that students also have concern for environmental issues (Wicaksono, Minarti, \& Roshayanti, 2018). This is what makes this waste plastic waste processing into one of the things that appeal to students.

Finally, the skills of these students, in addition, can be developed in the topic of plastic waste processing can also be developed in various materials. Students' skills are highly demanded on learning materials that require students to products. The hope of similar action research is also done to solve various problems in the classroom related to the students' skills. Efforts to improve learning in students actually not only done alone. Teachers can take various parties to find various solutions for learning problems. One way that can be used is to use lesson study that works together among teachers in a field.

\section{CONCLUSION}

There was an increasing trend of students' motoric skills in each cycle. The demonstration method can improve students' motoric skills in recycling plastic waste. Demonstration method make students' learn actively. This study was conducted only in one class, as was the case for classroom action research. This is certainly a limitation in this study that causes the results of this study cannot be generalized. Therefore, further research is needed in various classes and levels of education as well as with other research methods, such as quasi-experiment. It is also necessary to conduct research related to the impact of demonstration method on improving creative thinking and problemsolving skills of students.

\section{REFERENCES}

Adhitama, R. S., Kusnadi, K., \& Supriatno, B. (2014). Kesadaran metakognitif siswa dalam pembelajaran berbasis proyek pada pokok bahasan pencemaran lingkungan. ASIMILASI, I(1), 2-11.

Amin, M. (2010). Implementasi hasil-hasil penelitian bidang biologi dalam pembelajaran. In Seminar Nasional Pendidikan Biologi FKIP UNS (pp. 1218).

Andini, S. A., Susanto, S., \& Hobri, H. (2017). Students' activity in problem-based learning (PBL) math classroom be oriented lesson study for learning community (LSLC). International Journal of Advanced Research, 5(9), 1395-1400. https://doi.org/10.21474/IJAR01/5458

Anjarwati, D., Winarno, A., \& Churiyah, M. (2016). Improving learning outcomes by developing instructional media-based Adobe Flash Professional CS 5.5 on principles of business subject. IOSR Journal of Research \& Method in Education, 6(5), 1-6. https://doi.org/10. 9790/7388-0605010106

Arikunto, S. (2012). Dasar-Dasar Evaluasi Pendidikan. Jakarta: Bumi Aksara.

Basheer, A., Hugerat, M., Kortam, N., \& Hofstein, A. (2017). The effectiveness of teachers' use of demonstrations for enhancing students' understanding of and attitudes to learning the oxidationreduction concept. EURASIA Journal of Mathematics, Science and Technology Education, 13(3), 555-570. https://doi. org/10.12973/eurasia.2017.00632a

Bidokht, M. H., \& Assareh, A. (2011). Lifelong learners through problem-based and self directed learning. Procedia Computer Science, 3, 1446-1453. https://doi.org/10. 1016/j.procs.2011.01.028

Bulut, S. (2012). Value of demonstration in an instrumental course. Procedia - Social and Behavioral Sciences, 47(October 2001), 1064-1067. https://doi.org/10.1016/j.sbsp ro.2012.06.779

Cantell, M., Crawford, S. G., \& (Tish) DoyleBaker, P. K. (2008). Physical fitness and 
health indices in children, adolescents and adults with high or low motor competence. Human Movement Science, 27(2), 344-362. https://doi.org/10.1016/ j.humov.2008.02.007

Chuvgunova, O., \& Kostromina, S. (2016). Planning as a learning skill of students. Procedia-Social and Behavioral Sciences, 217, 132-138. https://doi.org/10.1016/j. sbspro.2016.02.045

Derri, V., \& Pachta, M. (2007). Motor skills and concepts acquisition and retention: a comparison between two styles of teaching. RICYDE. Revista Internacional de Ciencias Del Deporte, 3(9), 37-47. https://doi.org/10.5232/ricyde2007.00904

Donnelly, F. C., Mueller, S. S., Gallahue, D. L., \& Gallahue, D. L. (2017). Developmental physical education for all children: Theory into practice.

Doussoulin, A., \& Rehbein, L. (2011). Motor imagery as a tool for motor skill training in children. Motricidade, 7(3), 37-43. https://doi.org/10.6063/motricidade.7(3).1 31

Fauziyah, L., \& Jailani, J. (2014). Pengembangan perangkat pembelajaran matematika yang menunjang pendidikan karakter siswa kelas IV sekolah dasar. Jurnal Prima Edukasia, 2(2), 149-163. https://doi.org/10.21831/jpe.v2i2.2715

Gay, L. R., Mills, G. L., \& Airasian, P. (2012). Educational research: competencies for analysis and application. Boston: Pearson.

Hama, S. M., \& Hilal, N. N. (2017). Fresh properties of self-compacting concrete with plastic waste as partial replacement of sand. International Journal of Sustainable Built Environment. https://doi.org/10.1016/j.ijsbe.2017.01.001

Ichsan, I. Z., Rusdi, R., \& Sartono, N. (2017). Hasil belajar sistem saraf menggunakan film pendek. Biosfer: Jurnal Pendidikan Biologi, 10(2), 49-59. https://doi.org/10.2 1009/biosferjpb.10-2.7

Isbell, C., \& Isbell, R. T. (2007). On the move: Environments that stimulate motor and cognitive development in infants. Dimensions of Early Childhood, 35(3).

Islam, M. B., Ahmed, A., Islam, M. K., \& Shamsuddin, A. K. (2014). Child education through animation: An experimental study. International Journal of Computer Graphics \& Animation, 4(4), $43-52$. https://doi.org/http://dx.doi.org/10.5121/ij cga.2014.4404

Lederman, N. G., Lederman, J. S., \& Antink, A. (2013). Nature of science and scientific inquiry as contexts for the learning of science and achievement of scientific literacy. International Journal of Education in Mathematics Science and Technology (IJEMST), 1(3), 138-147. https://doi.org/10.18404/ijemst.19784

Loprinzi, P. D., Cardinal, B. J., Loprinzi, K. L., \& Lee, H. (2012). Benefits and environmental determinants of physical activity in children and adolescents. Obesity Facts, 5(4), 597-610. https://doi. org/10.1159/000342684

Loprinzi, P. D., Davis, R. E., \& Fu, Y.-C. (2015). Early motor skill competence as a mediator of child and adult physical activity. Preventive Medicine Reports, 2, 833-838. https://doi.org/10.1016/j.pmedr. 2015.09.015

McCullagh, P., \& Little, W. S. (1990). Demonstrations and knowledge of results in motor skill acquisition. Perceptual and Motor Skills, 71, 735-742. https://doi.org/ 10.2466/pms.1990.71.3.735

Navarro-Pablo, M., \& Gallardo-Saborido, E. J. (2015). Teaching to Training Teachers through Cooperative Learning. Procedia Social and Behavioral Sciences, 180(November 2014), 401-406. https:// doi.org/10.1016/j.sbspro.2015.02.136

Noah Ekeyi, D. (2013). Effect of demonstration method of teaching on students' achievement in Agricultural Science. World Journal of Education, 3(6), 1-7. https://doi.org/10.5430/wje.v3n6p1

Nordin, A. B., \& Alias, N. (2013). Learning Outcomes and Student Perceptions in Using of Blended Learning in History. Procedia-Social and Behavioral Sciences, 103, 577-585. https://doi.org/10.1016/j. sbspro.2013.10.375

Nugroho, E. D., Vlorensius, V., Rasidah H., L., \& Anisa, N. (2017). The content analysis, material presentation, and readability of curriculum 2013 science textbook for 1st semester of Junior High School 7th grade. JPBI (Jurnal Pendidikan Biologi Indonesia), 3(2), 114. https://doi.org/10. 22219/jpbi.v3i2.3904

Piek, J. P., Dawson, L., Smith, L. M., \& Gasson, N. (2008). The role of early fine and gross motor development on later 
motor and cognitive ability. Human Movement Science, 27(5), 668-681. https://doi.org/10.1016/j.humov.2007.11.0 02

Polizzotto, K., \& Tamari, F. (2015). Using lecture demonstrations to visualize biological concepts. Journal of Microbiology \& Biology Education, 16(1), 79-81. https://doi.org/10.1128/jmbe.v16i1 .840

Prajina, P. V. (2014). Impact of life skills among adolescents : A review, (2277), 3 4.

Pruneski, J., \& Donovan, S. (2007). The use of animations in undergraduate biology education: Going beyond the content!, (0937791), 937791.

Puspitorini, R., Prodjosantoso, A. K., Subali, B., \& Jumadi, J. (2014). Penggunaan media komik dalam pembelajaran ipa untuk meningkatkan motivasi dan hasil belajar kognitif dan afektif. Jurnal Cakrawala Pendidikan, 3(3), 413-420. https://doi.org/10.21831/cp.v3i3.2385

Ramsey, L. L., Walczyk, J., Deese, W. C., \& Eddy, D. (2000). Using demonstration assessments to improve learning. Journal of Chemical Education, 77(11), 1511. https://doi.org/10.1021/ed077p1511

Ranya, Z. A., Jamhari, M., \& Rede, A. (2013). Meningkatkan hasil belajar siswa dalam pembelajaran IPA pokok bahasan panca indra dengan menggunakan metode demonstrasi pada siswa kelas IV A SDN 5 Pusungi. Jurnal Kreatif Tadulako Online, 1(2), 60-66.

Sesen, B. A., \& Tarhan, L. (2010). Promoting active learning in high school chemistry: Learning achievement and attitude. Procedia-Social and Behavioral Sciences, 2(2), 2625-2630. https://doi.org/10.1016/j. sbspro.2010.03.384

Soika, K., Reiska, P., \& Mikser, R. (2010). The importance of animation as a visual method in learning chemistry. Concept Maps: Making Learning Meaningful, 3(10), 9 .

Surono, U. B., \& Ismanto. (2016). Pengolahan Sampah Plastik Jenis PP, PET, dan PE
Menjadi Bahan Bakar Minyak dan Karakteristiknya. Jurnal Mekanika Dan Sistem Termal, 1(11), 32-37.

Teodora Mihaela, I., \& Laurentiu-Gabriel, T. (2014). Teaching approach to enhance motor skills for students in primary school, 746-751. https://doi.org/10.1016/j. sbspro.2014.09.314

Umar, M. A., Bala, D., \& Ladu, K. M. (2016). Effectiveness of demonstration and lecture methods in learning concept in economics among secondary school students in Borno State, Nigeria. Journal of Education and Practice, 7(12), 51-59.

Uzun, N. (2012). A Sample of active learning application in science education: the thema "cell" with educational games. Procedia-Social and Behavioral Sciences, 46, 2932-2936. https://doi.org/10.1016/j.s bspro.2012.05.592

Vrbik, I., \& Vrbik, A. (2017). Video demonstration as a teaching method. Croatian Journal of Education, 19(2), 201-213. https://doi.org/10.15516/cje.v19i 0.2674

Walker, D. E. T. (2003). The importance of media in the classroom. In What Every Teacher Should Know About Media and Technology (pp. 1-7).

Wicaksono, A. G. C., Minarti, I. B., \& Roshayanti, F. (2018). Analysis of students' science motivation and nature of science comprehension in middle school. JPBI (Jurnal Pendidikan Biologi Indonesia), 4(1), 35-42. https://doi.org/ 10.22219/jpbi.v4i1.5354

Yusuf, M. M., Amin, M., \& Nugrahaningsih, N. (2017). Developing of instructional media-based animation video on enzyme and metabolism material. JPBI (Jurnal Pendidikan Biologi Indonesia), 3(3), 254257. https://doi.org/10.22219/jpbi.v3i3.47 44

Ziegler, A., \& Stoeger, H. (2010). How fine motor skills influence the assessment of high abilities and underachievement in Math. Journal for the Education of the Gifted, 34(2), 195-219. 